\title{
La storia a portata di mano per ri-costruire la memoria di una comunità
}

\author{
Stefano Fasolini \\ Ivana Passamani \\ Nicola Ghidinelli \\ Andrea Pasini
}

Abstract

Gavardo è una cittadina situata a est di Brescia in cui i segni naturali e antropici parlano anche di una storia non sempre benevola. La ricerca ha inizialmente identificato le procedure per fornire in maniera facilmente accessibile, ad un vasto numero di utenti, un database progressivamente implementabile in modalità open source, con lo scopo di raccogliere, organizzare, georeferenziare e comunicare comparativamente la totalità di dati eterogenei legati al patrimonio culturale ed architettonico del caso-studio. Un successivo sviluppo prevede una videoricostruzione tridimensionale di una porzione del tessuto urbano storico del paese, andato perduto durante un tragico bombardamento aereo sul finire della seconda guerra mondiale. Questa attività permette di ricostruire virtualmente edifici e spazi urbani scomparsi da decenni, facendo rivivere in chi è rimasto la memoria di persone e di una storia solo apparentemente dimenticata.

II metodo informativo proposto nella ricerca si dimostra quindi sempre più uno strumento efficace nel preservare e trasmettere la memoria di un determinato luogo, non solo per la conoscenza dell'esistente, ma anche per la ricostruzione virtuale di spazi perduti e di aspetti sociali che sembrano non esistere più, ma che possono ancora avere un ruolo di guida nelle scelte future del disegno dei luoghi.

Parole chiave

archivio digitale, ricostruzione virtuale, rappresentazione, accessibilità, disseminazione.

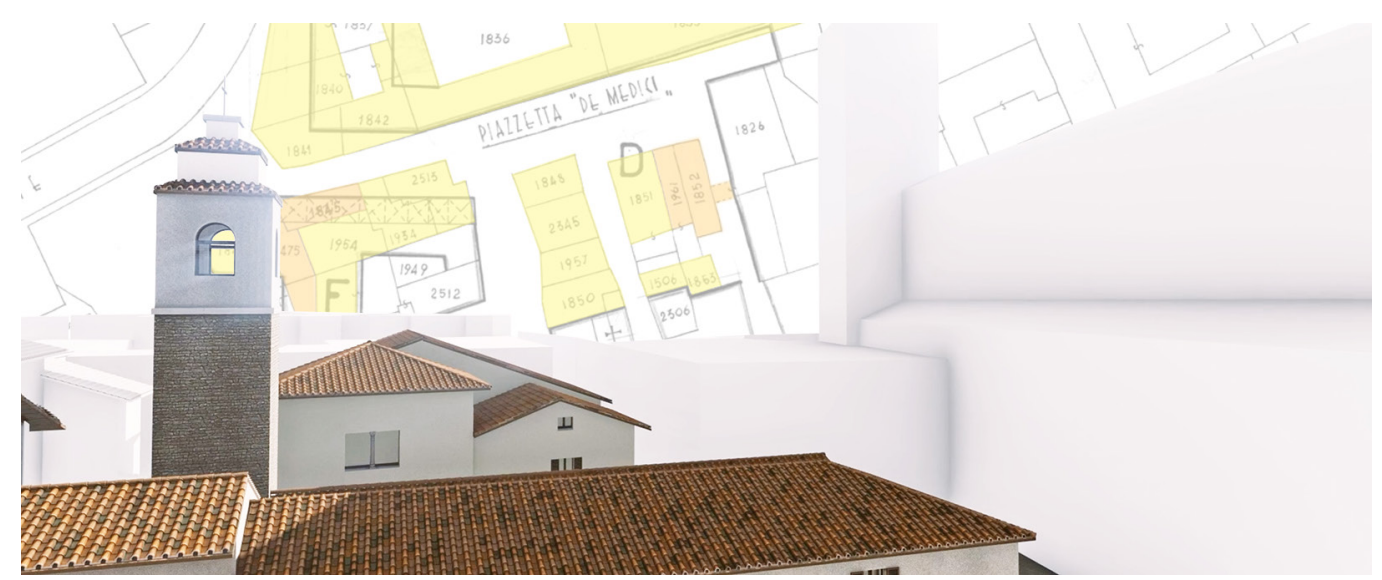




\section{L’oggetto di studio}

Quando una comunità locale viene colpita da un evento bellico nel luogo in cui vive non perde solo vite umane e non perde solo edifici e oggetti. Se l'assenza di un singolo pezzo rappresenta un vuoto incolmabile per il singolo, il valore della perdita per la comunità tutta è incommensurabile ed ha ricadute che si ripercuotono nel tempo anche sulle generazioni a venire $[\mathrm{I}]$. Esse inconsapevolmente vivono in spazi urbani che hanno apparentemente ricucito gli squarci e le ferite, percorrono dei vuoti laddove c'erano fitte trame abitate e pulsanti di suoni, odori e sapori.

E utile consegnare al presente una storia che non sia solo raccontata a voce o scritta, e far rivivere luoghi cancellati piuttosto che mostrarli in sbiadite immagini dell'epoca?

L'attività di ricerca qui presentata assume come punto di avvio il tragico evento del bombardamento di Gavardo, che il 29 gennaio 1945 interessò il cuore del borgo cancellandone alcuni isolati: fu uno spartiacque tra un prima e un dopo, una ferita difficile da curare, come dimostra il fatto che le macerie rimasero per anni nello spazio urbano, accanto ad una comunità che non trovava un modo di ripensare i luoghi feriti.

Non è stato quindi semplice affrontare questo tema.

L'obiettivo era quello di riconsegnare un pezzo di storia alla comunità. L'operazione si appoggiava ad alcuni concetti o parole chiave ineludibili:

- comprensione/semplificazione: la complessità della storia locale deve essere semplificata per arrivare a tutti gli utenti e deve essere 'metabolizzabile'. Gli strumenti e i linguaggi devono essere semplici, adattabili ai diversi dispositivi;

- implementazione/partecipazione: l'utente può contribuire ad arricchire il database (open source);

- ricucitura: si deve realizzare un ponte culturale per sanare una lacuna;

- accessibilità/inclusività: la restituzione della memoria è rivolta a tutta la comunità quindi il requisito dell'accessibilità deve declinarsi in inclusività. Questo comporta la predisposizione di pannelli tattili o modellini, oltre a video con linguaggio LIS.

Il progetto è quindi articolato in più azioni, la prima delle quali ha avuto l'obiettivo di impostare una 'scatola della memoria' accessibile, un archivio digitale sempre implementabile ed open source che trasformi gli indizi in pezzi di un puzzle da ricomporre per riconsegnare la storia urbana in modo comprensibile, per dipanare i fatti e le corrispondenze con il tessuto edilizio [2].

Si presenta nel contributo la seconda azione: attualmente ad uno stato avanzato, prevede la predisposizione di una videoricostruzione virtuale del centro storico prima del bombardamento, che consenta di riconsegnare alla comunità quella forma urbis perduta e mai ricucita. Un'anteprima della ricerca in corso e del video sono stati proposti in occasione delle ce-

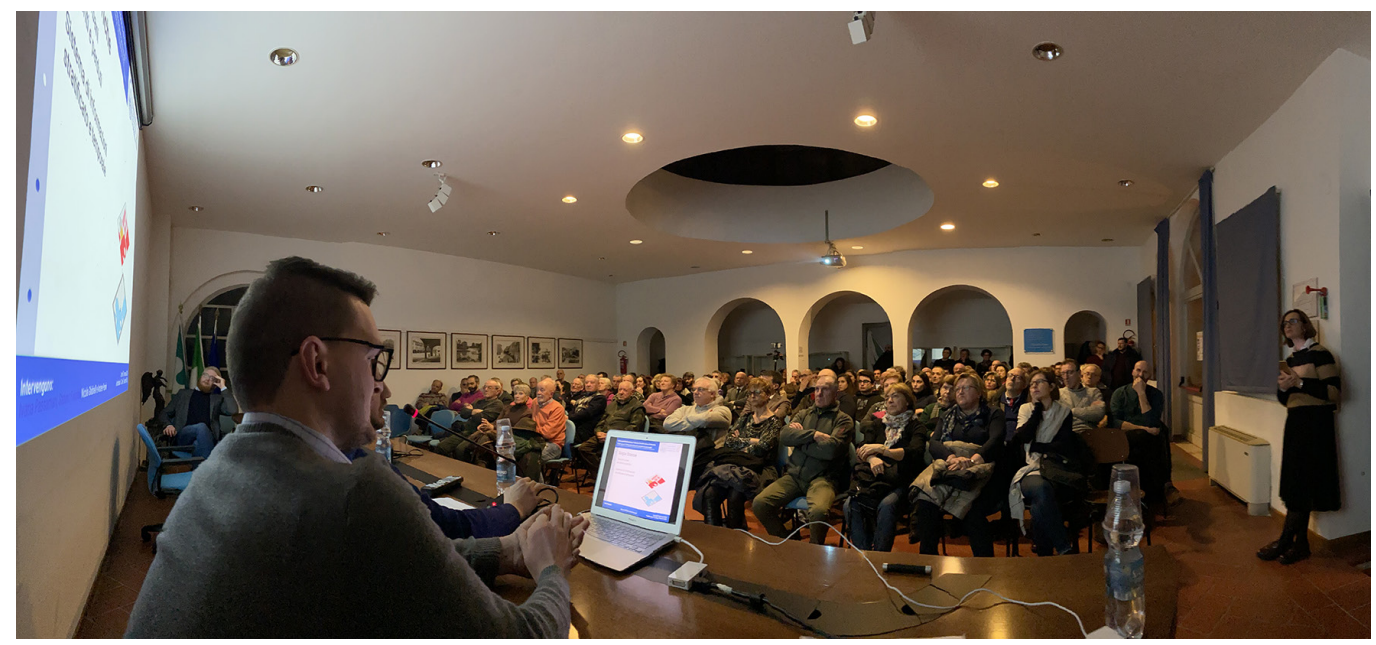


lebrazioni del $75^{\circ}$ anniversario del bombardamento [3]: una sala gremita in cui, affiancati ai pochi che avevano vissuto direttamente l'evento, molti cittadini hanno potuto calarsi tra le vie del borgo, visualizzare le botteghe e le attività, avere in mano la loro storia (fig. I).

La ricostruzione si appoggia a foto e disegni dell'epoca per vestire i volumi. Riteniamo anche efficace la versione spoglia. Fa pensare a quando si entra in un ambiente chiuso da tanto tempo e si vedono le lenzuola bianche che coprono i mobili, lasciando intuire le forme sottostanti.

La versione spoglia del modello 3D può permettere a chi toglierà quel lenzuolo di avere a portata di mano la propria storia (fig. 2).

Fig. 2. Ricostruzione virtuale del centro storico di Gavardo in un fotogramma del video privo di annotazioni architettoniche, materiche, cromatiche (elaborazion grafica N Ghidinelli. A Pasini).

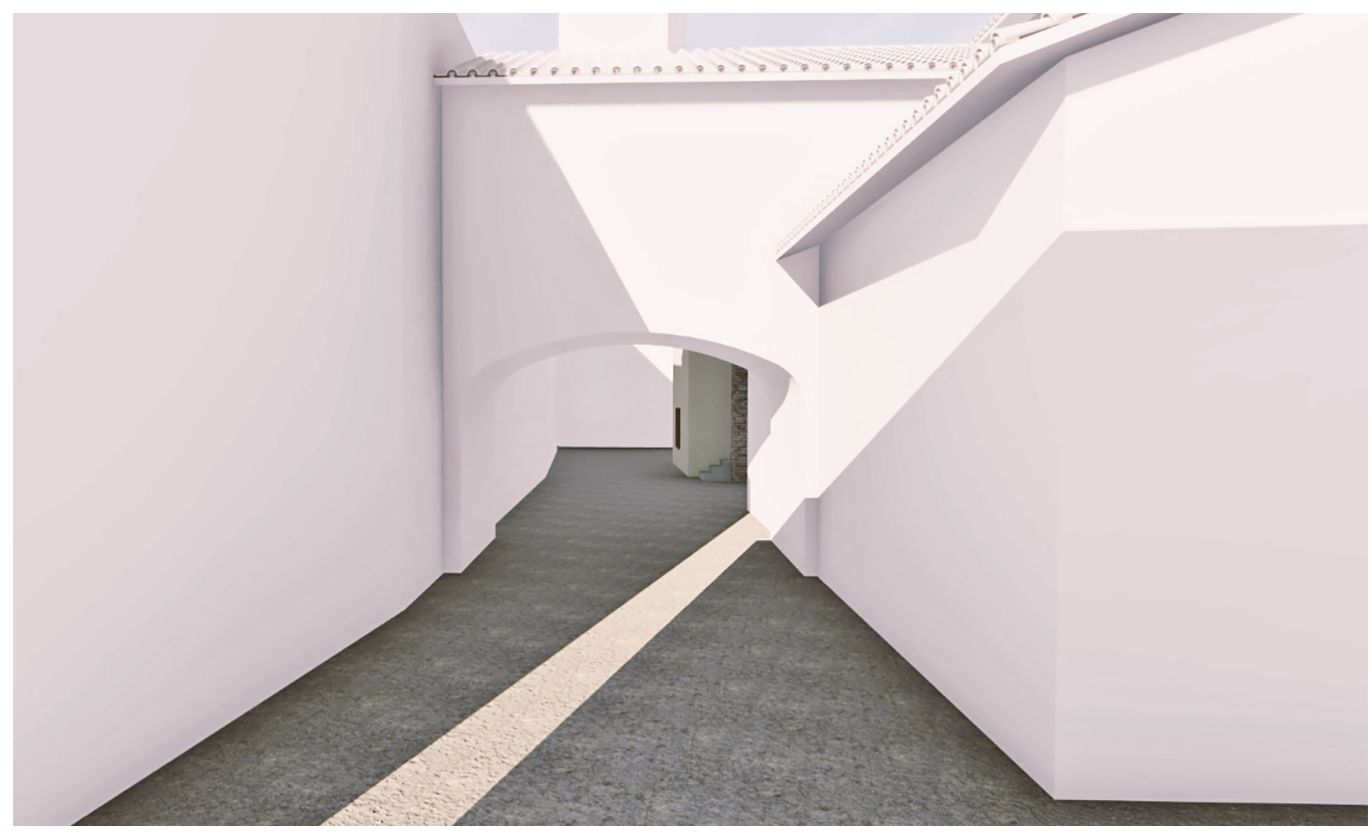

\section{Uno strumento per l'identità di una comunità}

È ragionevole pensare che l'identità di una comunità si esprima anche in funzione dei luoghi che essa vive, dei quali l'occhio del ricercatore attento può leggere sul territorio i segni e i disegni, siano essi di natura antropica o meno (fig. 3).

Ricordando quanto scrisse Gianfranco Caniggia sulla lezione di Saverio Muratori riguardante la morfologia del centro abitato, esso è "organismo in divenire, quindi non può che mostrare il 'suo essere divenuto', quindi i suoi attuali caratteri strutturali, attraverso momenti di formazione-trasformazione in successione, ricostruibili mediante la ricostruzione logica e analogica del succedersi di fasi, di volta in volta finite, rappresentabili graficamente" [Caniggia 1988, p. 144]. Le diverse fasi possono quindi essere rappresentate graficamente, secondo modi che non possono che essere declinati di volta in volta diversamente, in funzione delle innovazioni che la tecnologia continuamente ci propone. L'efficacia di questa ricerca nello studio di un centro abitato sta proprio nella possibilità che essa offre di fornire uno strumento al passo con i tempi in cui viviamo, autorevole per la comprensione del costruito, ma al tempo stesso facilmente sfruttabile da una vasta platea di utenti, gli stessi che potranno implementare le informazioni presenti nel database, garantendone l'aggiornamento costante. Uno strumento di questo tipo, in continuo sviluppo ed evoluzione, può senz'altro risultare funzionale ad una maggiore consapevolezza da parte degli organi tecnici in fase di programmazione urbanistica o di intervento architettonico sull'esistente, ma può garantire un passo ulteriore. Permettendo la ricostruzione virtuale di un ambito di Gavardo andato distrutto durante i bombardamenti della Seconda guerra mondiale, esso ha infatti dimostra- 
to non solo la capacità di funzionare adeguatamente per garantire il valore architettonico del tessuto urbano, ma anche per salvaguardarne ed esaltarne il valore sociale, costituito di relazioni e di aggregazioni, prima che di edilizia, l'attenuarsi del quale provoca un danno difficilmente rimediabile nel tempo, assai più di un danneggiamento fisico.

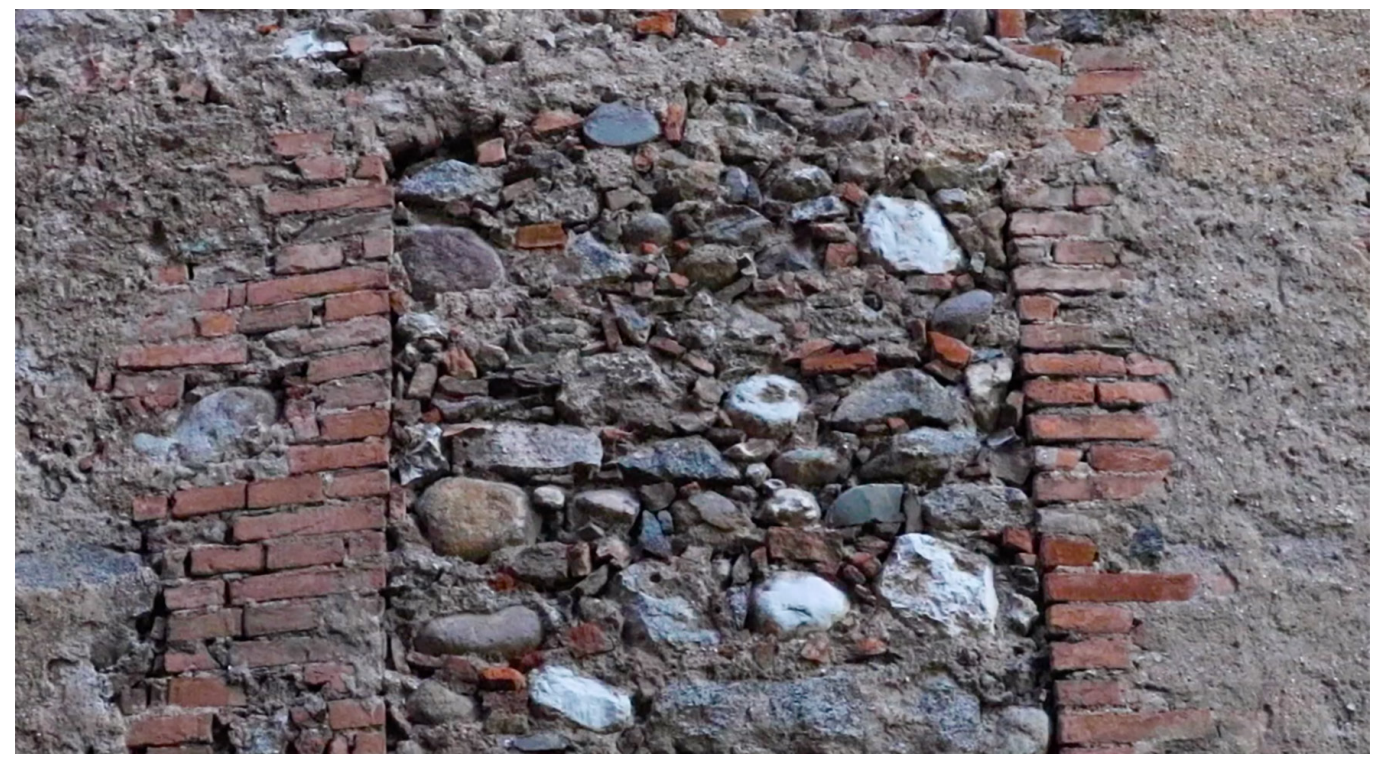

\title{
II metodo informativo
}

Il patrimonio culturale di un territorio è un sistema articolato di immagini e situazioni stratificate generate dalla successione di vicende naturali e antropiche.

II metodo si pone l'obbiettivo principale di raccogliere i dati eterogenei derivanti dalla ricerca e dal rilevamento e di sistematizzarli all'interno di uno spazio che sia facilmente accessibile a diverse tipologie di utenti e che ne permetta la valorizzazione, così da rendere

\section{Ricerca archivistica e bibliografica}

\author{
"Sapere" \\ Linee guida

\section{Dati eterogenei}
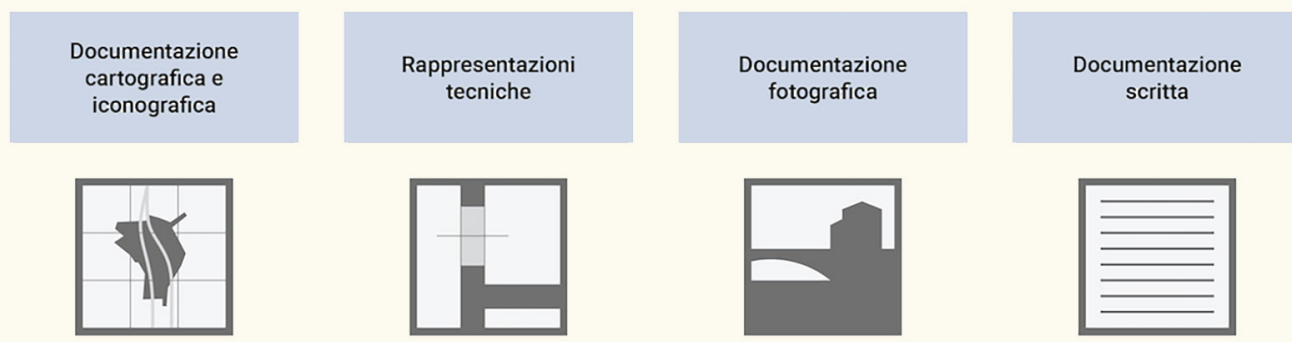
fruibile il patrimonio culturale, storico, economico, naturalistico di un territorio e favorire la conoscenza, la responsabilizzazione e la partecipazione degli abitanti (fig. 4).

Per favorire il più alto coinvolgimento di utenti è importante che il database sia sviluppato secondo i dettami del responsive web design così da facilitarne l'approccio, che sia open source affinché l'utente stesso possa offrire, sottoponendo i propri contributi al curatore, il proprio apporto di memoria e conoscenza dei luoghi, nonché open content, così che i contenuti dell'archivio virtuale siano condivisi.

II principio fondamentale che ci permette di perseguire questi obbiettivi è la geolocalizzazione delle informazioni all'interno di un ambiente digitale, grazie alla quale la consultazione e l'uso dei database assumono caratteri di efficienza, di precisione e di attendibilità.

GavArch

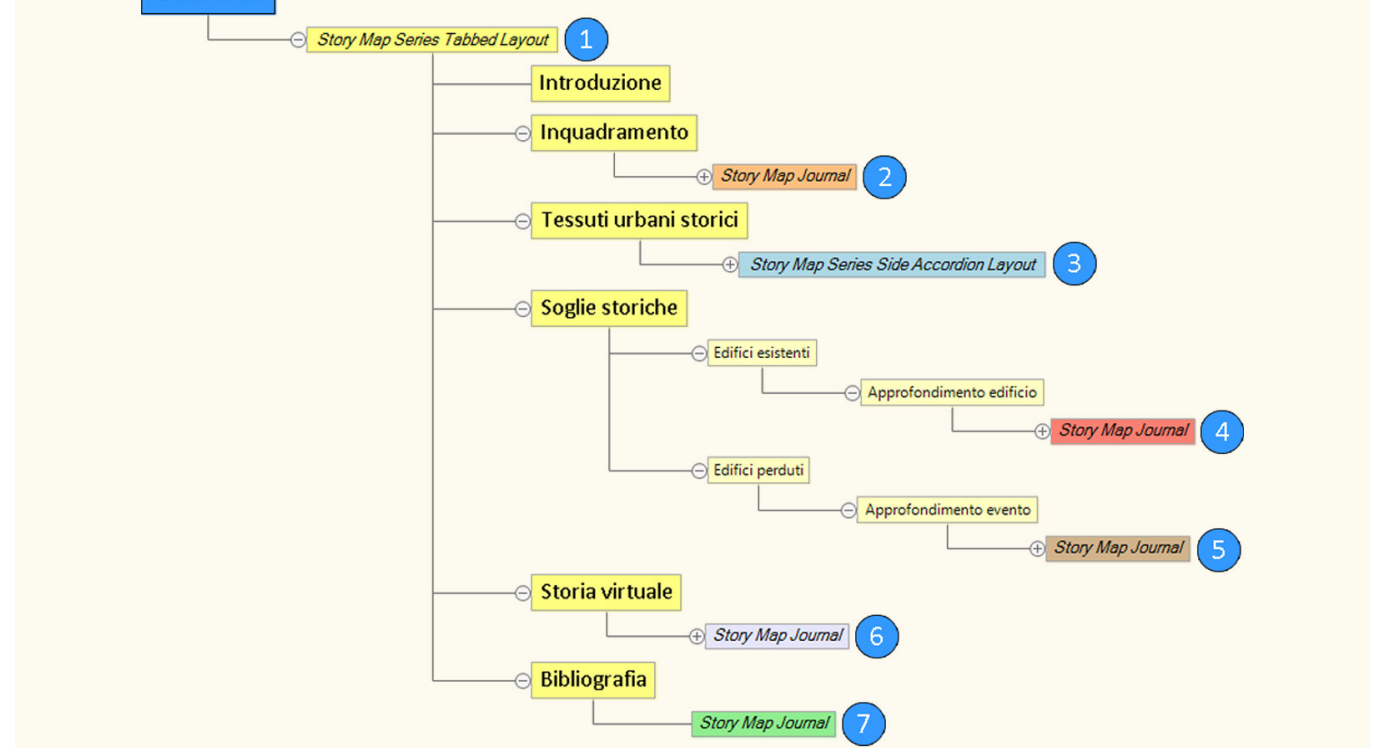

Per poter riassumere lo studio morfologico urbano di un territorio, è stato necessario creare una base alla quale collegare i dati di tipo storico, classificando i tessuti urbani in base alla loro epoca di appartenenza, mettendo in luce quelli esistenti e quelli andati perduti e formando così un sistema di informazioni stratificato e dotato di una dimensione temporale. Operativamente, mediante l'analisi e la rielaborazione virtuale delle varie cartografie storiche e la loro sovrapposizione attraverso i punti cardine dell'esistente è stato possibile ricostruire i tessuti urbani relativi alle varie soglie storiche.

Attraverso l'utilizzo di Sistemi Informativi Territoriali, tramite l'impiego di un software GIS (Geographic Information System), è stato possibile elaborare e organizzare i dati e collegarli a specifiche entità territoriali, riferendoli spazialmente alla superficie terrestre grazie alle loro coordinate geografiche (fig. 5).

Utilizzando un'estensione webGIS del software è stato possibile condividere e gestire in rete le mappe creando quindi degli applicativi, denominati Story Map in grado di combinare le mappe con testi narrativi e contenuti multimediali di vario genere utilizzando dei modelli predefiniti caratterizzati da un'interfaccia grafica intuitiva di facile comprensione e progettata in modo da adattarsi automaticamente ai vari supporti utilizzati (smarphone, tablet, PC). All'interno dell'applicazione, la mappa delle soglie storiche è stata sovrapposta a una base ortofotografica ed è stato possibile gestire la veste grafica ed attribuire dei dati di tipo alfanumerico agli elementi della mappa inserendo per ogni edificio delle informazioni relative al nome, all'epoca di costruzione, alla tipologia di utilizzo e tipologia di costruzione, all'indirizzo in cui è ubicato permettendo poi di accedere ad un livello di approfondimento ulteriore. 
Fig. 6. Vista dalla scheda Soglie Storiche del sistema informativo grafica di N Ghidineli, grafica di

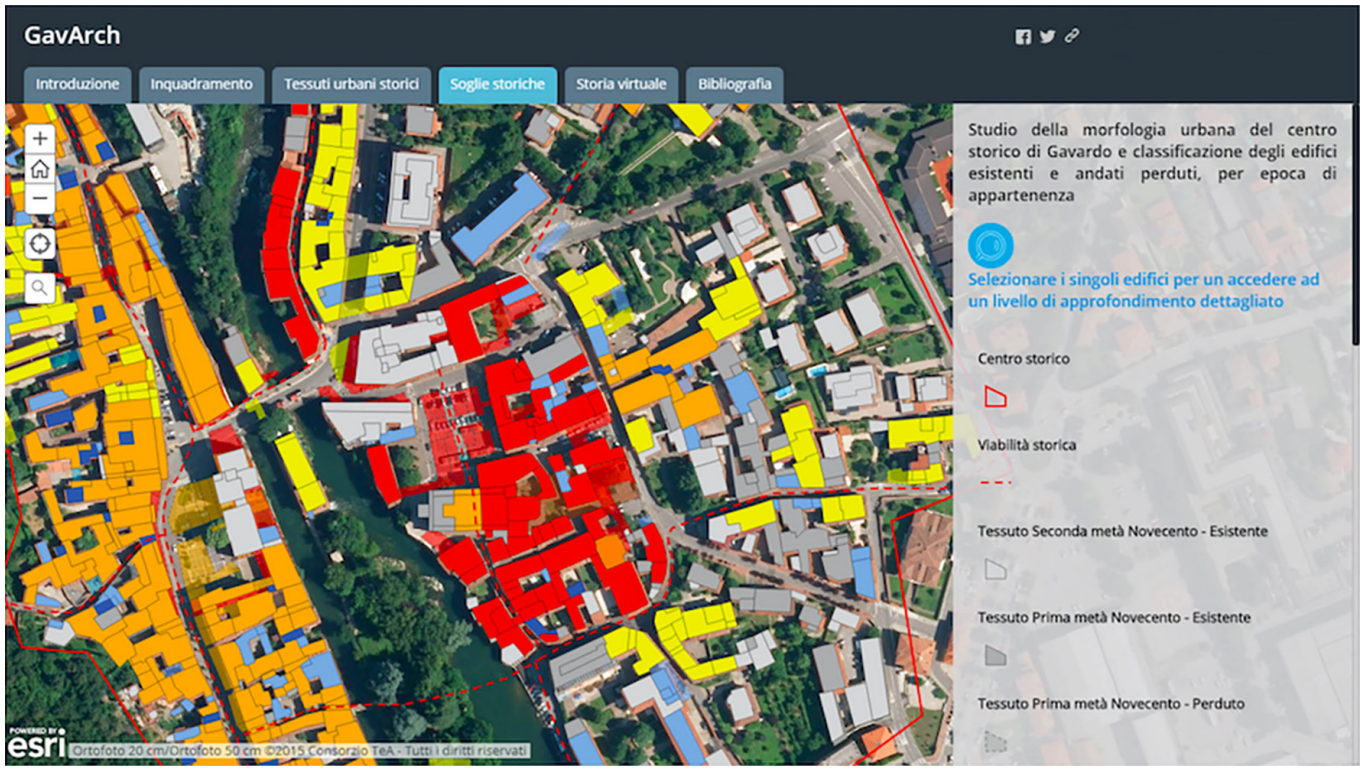

Sono state create sette Story Map legate tra loro tramite dei collegamenti ipertestuali a cui è associato un codice URL, costituendo così la struttura generale di base, configurata attraverso l'interfaccia grafica e le funzionalità del template Map Series Tabbed Layout (fig. 6). Attraverso questo approccio è possibile valorizzare i dati e comprendere e conoscere la storia di un luogo sia dal punto di vista culturale che dal punto di vista tecnico, andando a creare un supporto per i professionisti e per le amministrazioni locali che possano agire attraverso scelte progettuali coscienziose.

Negli sviluppi futuri, considerando un'accessibilità di tipo sensoriale, si potrà elaborare le informazioni in supporti tattili e modelli plastici scomponibili in modo da rendere fruibile il metodo anche agli utenti deboli.

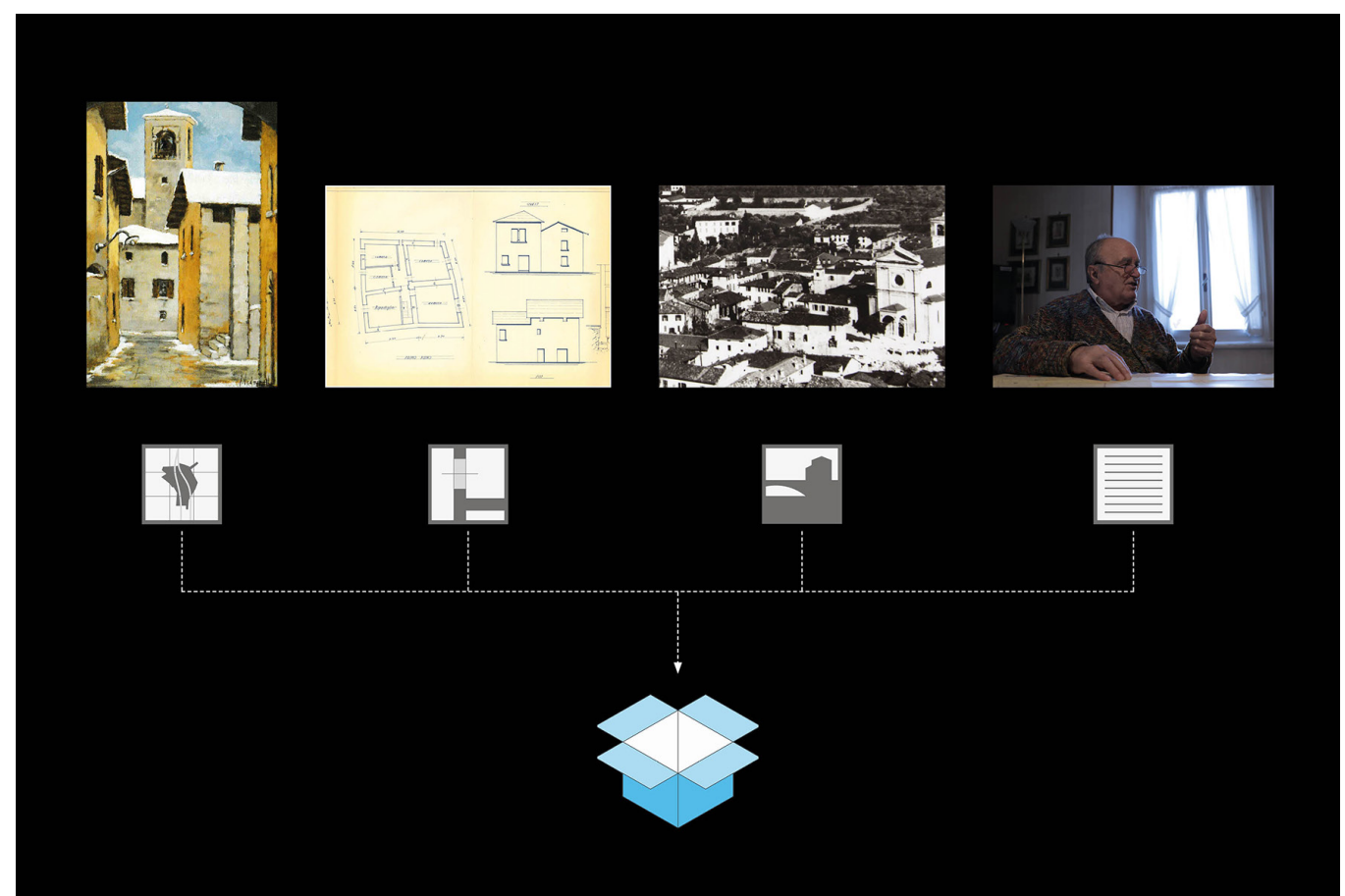




\section{La ricostruzione digitale}

II risultato della sovrapposizione delle informazioni che si viene a creare all'interno della stratificazione temporale delle soglie storiche mostra un complesso sistema di sedimi di edifici esistenti e di altri perduti appartenenti a differenti epoche che, se interpretato e studiato puntualmente, consente di sviluppare una ricostruzione digitale efficace e comunicativa, con un livello di leggibilità maggiore e di alto dettaglio.

L'idea di sviluppare una ricostruzione tridimensionale in ambito digitale di un luogo andato perduto è la naturale conseguenza della possibilità di potere disporre di un sistema informativo che integra al suo interno informazioni differenti e derivanti dalla ricerca archivistica (dati cartografici e iconografici, dati geometrici, dati fotografici e dati descrittivi).

Questo processo richiede in primo luogo la corretta interpolazione delle informazioni già disponibili nel database e, più nello specifico, il ritrovamento di dati geometrici circa la terza

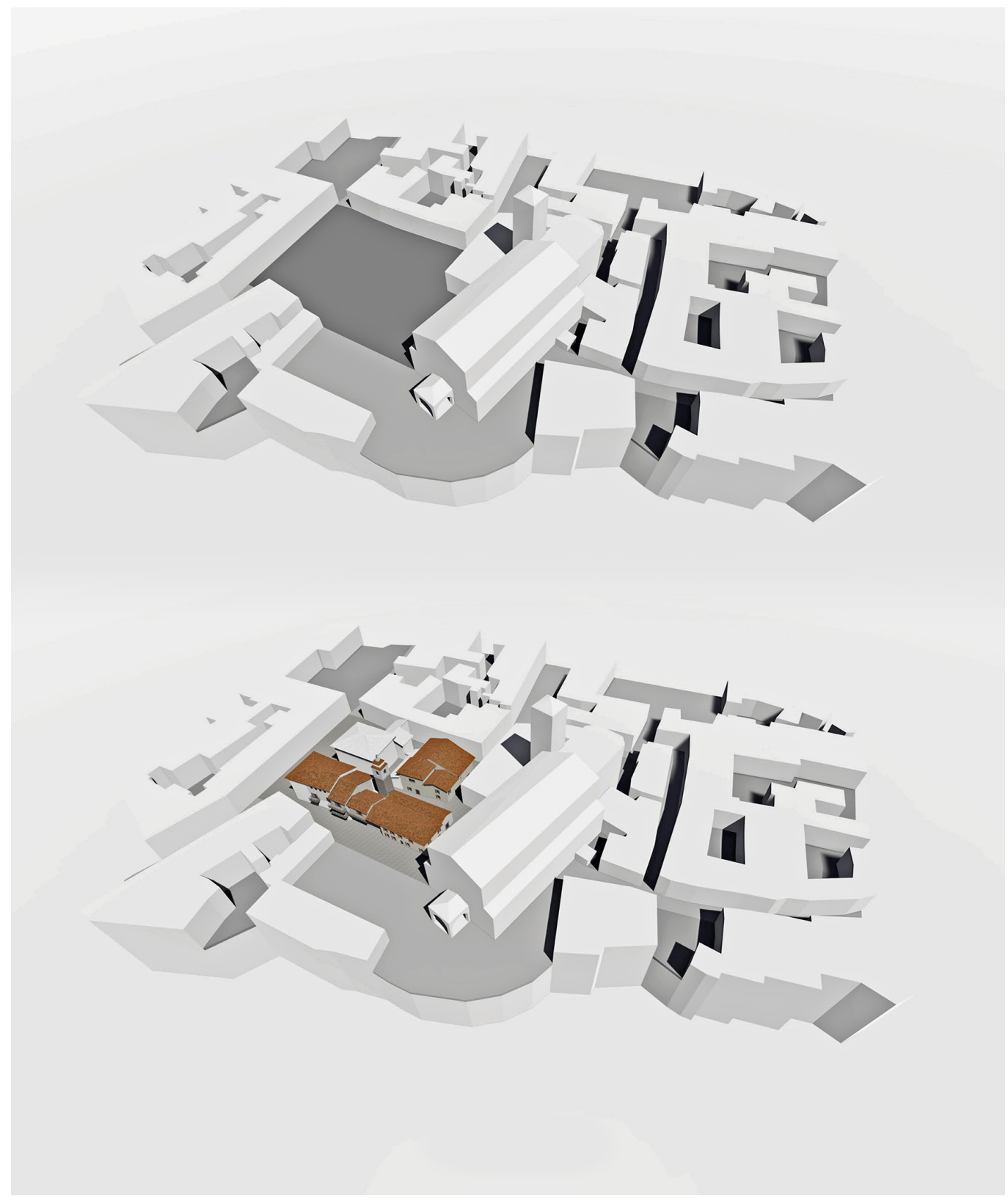


dimensione (altezza) degli edifici perduti e di dati visuali che descrivano correttamente l'involucro originario degli stessi al fine di potere ottenere un risultato il più possibile realistico. Questa operazione avviene attraverso un processo di riprogettazione del disegno (trascrittura di tutte le informazioni, selezione, verifica ed interpretazione delle stesse) con conseguenti scelte e interpretazione dei dati da comunicare. A tal fine, per dare un riscontro scientifico alla ricostruzione, si individuano differenti livelli di sviluppo dei dettagli così da dare una riedificazione volumetrica qualitativa laddove sono presenti meno informazioni e una realistica nel caso siano a disposizione maggiori informazioni.

Allinterno di questo processo di ricostruzione virtuale è importante reperire ulteriori informazioni di tipo narrativo-descrittive, attraverso le testimonianze di persone che abbiano vissuto e frequentato questi luoghi andati perduti. È importante sottolineare questa ricerca ambivalente: da un lato ritrovare e inseguire un dato e un'informazione perduta e in modo vicendevole preservare questo dato e informazione che subito si trasforma in patrimonio, memoria e dato archivistico condiviso in termini di valorizzazione, accessibilità e conoscenza (fig. 7).

I dati raccolti, una volta interpretati, sono stati combinati tra loro attraverso il metodo sopra descritto e implementati, ridisegnati, verificati e analizzati all'interno di un software di modellazione $3 \mathrm{D}$ per garantire una leggibilità e una modalità comunicativa fruibili dal più ampio numero possibile di utenti. Si è andati quindi ad effettuare un ridisegno morfologico con conseguente studio di forme, elementi e volumi.

Successivamente, attraverso l'utilizzo di software che consentono la traduzione del modello in rendering 3D, è stato sviluppato un ridisegno in termini di trattamento di superficie materica (texture, scelta, valutazione e combinazione materiali) e contemporaneamente operazioni di elaborazione di disegno e composizione immagine-atmosfera e montaggio scena (scelta e variazione differenti tipologie di resa grafica, gestione effetti luce, scelta taglio comunicativo, percorsi di presentazione e personalizzazione del racconto visuale), (fig. 8). Questo tipo di approccio, contestualmente alla presentazione della ricostruzione tridimensionale dei luoghi andati perduti a un gruppo di persone eterogeneo, consente di prefigurare ulteriori scenari per lo sviluppo futuro.

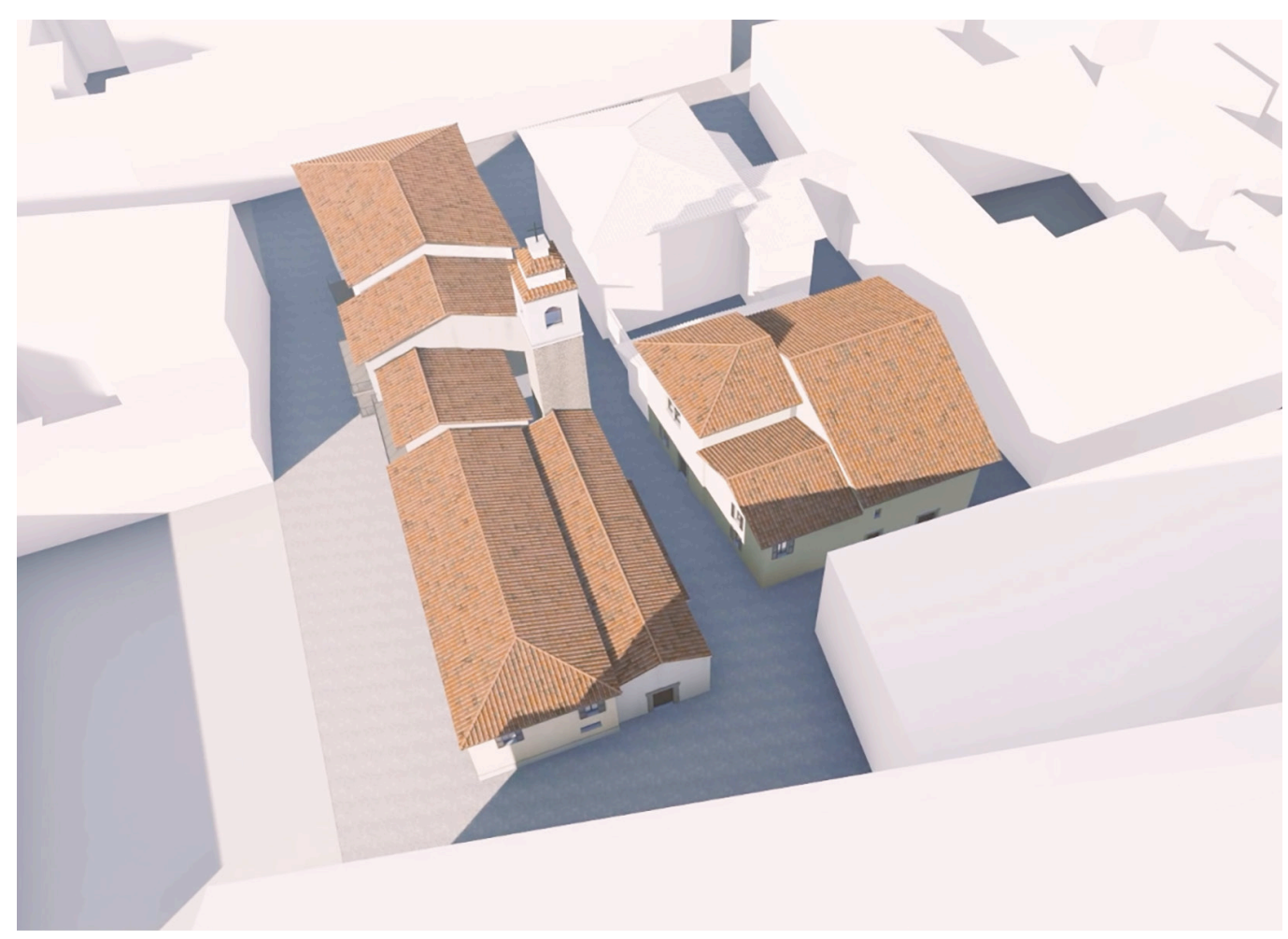


Obiettivi perseguiti e raggiunti

Davanti ad una traccia, a un indizio della memoria urbana, abbiamo tutti gli strumenti per intraprendere una ricerca su più livelli, finalizzata all'acquisizione di dati che consentano una ricostruzione o una ricucitura della lacuna. Questo processo, calato nella realtà urbana, apre nuovi scenari di conoscenza che, oltre al dato meramente architettonico, aggiungono quello umano e sociale. Si conquisterà così il valore più importante, quello dell'intima correlazione tra edifici, spazi urbani e l'umanità che li abitava e li viveva.

Nelle video ricostruzioni tridimensionali, allora, noi possiamo percorrere idealmente quegli spazi perduti sentendo riecheggiare i suoni della vita quotidiana e delle attività che lì erano presenti, e ricollocando nel giusto luogo destinazioni d'uso e persone: possiamo cioè riportare alla luce brani della storia locale cancellati in pochi secondi (fig. 9).

È quindi davvero utile e importante mettere 'a portata di mano' la scatola della memoria, ovvero costruire un sistema e un metodo informativi che preservino e rendano accessibili la storia e il patrimonio immateriale di un determinato luogo.

Grazie alle attuali tecnologie possiamo non solo ricostruire i luoghi distrutti, ma anche riproporre gli aspetti sociali e umani di un frammento storico. Da questi la comunità di oggi può trarre insegnamento, senso di coesione e solidarietà, considerandoli come volano e motore di scelte e conoscenze future per un tramandare coerente del disegno dei luoghi (fig. I0).

"La più grande perdita di questo tragico evento non possono essere solo gli edifici. Ricostruire la loro storia porta alla luce un'umanità andata perduta.

Avere a portata di mano questa storia consente di mantenere viva la memoria di una comunità".

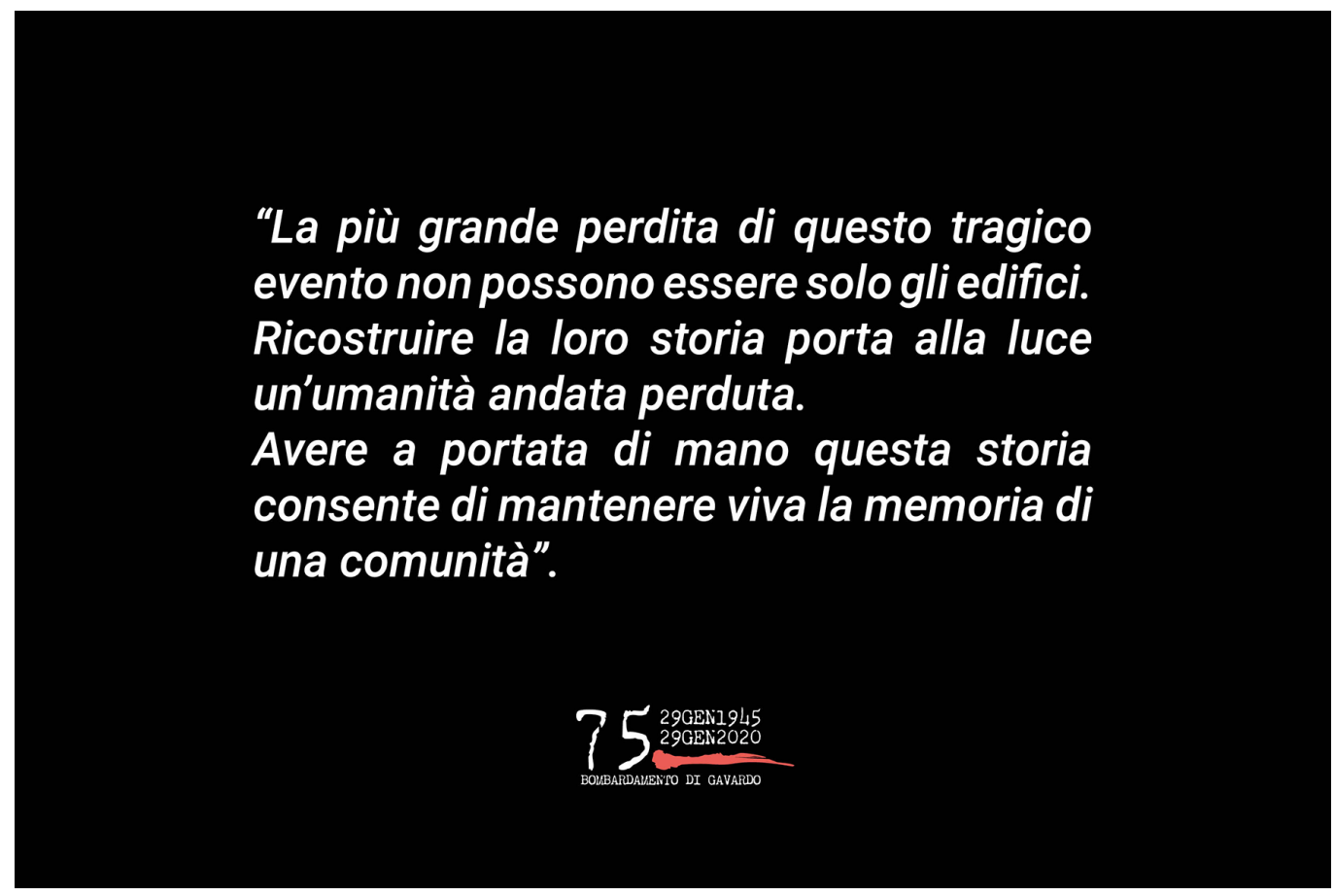

Note

[ I] Pur avendo condiviso obiettivi, metodologie e risultati della ricerca, si evidenzia che Passamani è autore dei paragrafi L'oggetto di studio e Obiettivi perseguiti e raggiunti; Fasolini del paragrafo Uno strumento per l'identità di una comunità; Ghidinelli del paragrafo II metodo informativo; Pasini del paragrafo La ricostruzione digitale.

[2] Questo primo passo è oggetto del paper A virtual archive to understand and communicate places' complexity ed è stato presentato nel settembre 2019 al Convegno STC 2019 a Salerno. II gruppo di ricerca era composto da Passamani, Fasolini, Pasini e Ghidinelli.

[3] L'evento è stato organizzato dall'Amministrazione Comunale nell'ambito delle manifestazioni per la commemorazione della tragedia. L'intervento La storia a portata di mano per ricostruire il nucleo storico di Gavardo è stato proposto il 27 gennaio 2020 a Gavardo. Ė intervenuto tutto il gruppo di ricerca. 


\section{Riferimenti bibliografici}

Bartolini Fabio (20I5). Dalla carta antica al sistema informativo territoriale: evoluzione storica dell'antico Canale dei Molini di Cesena. Cesena: Stilgraf.

Bruni Conter Gianbattista (2002). Quaderni della Quadra di Gavardo. Contributi alla conoscenza storica di un territorio. Numero 4. Brescia: Grafo2

Caniggia Gianfranco (1988). Saverio Muratori. La didattica e il pensiero. In Montuori Marina (a cura di). Lezioni di progettazione. 10 maestri dell'architettura italiana. Milano: Electa.

Cetraro Faustino (20 I I). Gis e WebGis a confronto. Cartografia applicata ai sistemi informativi territoriali. Roma: EPC Editore.

Chiavoni Emanuela, Docci Mario (2017). Saper leggere l'architettura. Bari: Editori Laterza.

Coppo Secondino (2002). Appunti di viaggio, un mazzo di fiori. In Mezzetti Carlo (a cura di) Gaspare de Fiore. Disegni, incisioni progetti. Roma: Edizioni Kappa.

Fappani Antonio (a cura di) (1993). Enciclopedia Bresciana, Volume X. Brescia: Fondazione Opera Diocesana San Francesco di Sales

Fasolini Stefano (2007). I borghi del Bresciano. Proposta di rappresentazione simbolica per lo studio dei centri mercantili minori. Tesi di dottorato di ricerca in Beni Culturali. Politecnico di Torino. Tutor prof. Secondino Coppo.

Graci Giancarlo, Pileri Paolo, Sedazzari Marco (2008). GIS e ambiente. Guida all'uso di ArcGIS per l'analisi del territorio e la valutazione ambientale. Palermo: Dario Flaccovio Editore.

Munari Bruno (1992). Semplificare è più difficile. In Munari Bruno. Verbale scritto. Mantova: Corraini Edizioni.

Munari Bruno (2016). I laboratori tattili. Mantova: Corraini Edizioni. (I ed. 1985).

Passamani Bonomi Ivana (2009). Le acque di Gavardo. In Salvatore Nocivelli Laura (a cura di). Brescia nel solco del fiume Chiese. Roccafranca: Compagnia della Stampa.

Passamani Ivana, Fasolini Stefano, Ghidinelli Nicola, Pasini Andrea (2019). Un archivio virtuale per comprendere e comunicare la complessità dei luoghi. In Fiore Pierfrancesco, D'Andria Emanuela (a cura di). Small towns... from problem to resource. Sustainable strategies for the valorization of building, landscape and cultural heritage in inland areas. Milano: Franco Angeli

Associazione Museo "Gruppo Grotte", Biblioteca Civica "E. Bertuetti" (1984). Gavardo da salvare: il patrimonio abitativo di Gavardo, Sopraponte e Soprazocco. Gavardo.

Associazione Museo "Gruppo Grotte”, Biblioteca Civica "E. Bertuetti” ( 1988). II volto storico di Gavardo, Gavardo: Industrie grafiche.

\section{Autori}

Stefano Fasolini, Università degli Studi di Brescia, stefano.fasolini@unibs.it.

Ivana Passamani, Università degli Studi di Brescia, ivana.passamani@unibs.it

Nicola Ghidinelli, Università degli Studi di Brescia, ghidinelli.nicola@gmail.com

Andrea Pasini, Università degli Studi di Brescia, andreapasini2290@gmail.com

Per citare questo capitolo: Fasolini Stefano,Passamani Ivana, Ghidinelli Nicola, Pasini andrea (2020). La storia a portata di mano per ri-costruire la memoria di una comunità/History at your doorstep acknowledging the legacy of a community. In Arena A., Arena M., Brandolino R.G., Colistra D., Ginex G., Mediati D., Nucifora S., Raffa P. (a cura di). Connettere. Un disegno per annodare e tessere. Atti del $42^{\circ}$ Convegno Internazionale de Docenti delle Discipline della Rappresentazione/Connecting. Drawing for weaving relationships. Proceedings of the 42th International Conference of Representation Disciplines Teachers. Milano: FrancoAngeli, pp. 2|42-2161. 


\title{
History at Your Doorstep Acknowledging the Legacy of a Community
}

\author{
Stefano Fasolini \\ Ivana Passamani \\ Nicola Ghidinelli \\ Andrea Pasini
}

Abstract

Gavardo is a town located east of Brescia where natural and anthropic signs also tell of a history that has not been always benevolent. The research initially identified the procedures to provide a vastly implementable database, easily accessible to a large number of users, with the aim of collecting, organizing, geo-referencing and comparatively communicating the totality of heterogeneous data related to the cultural and architectural aspects of the Gavardo case study. A subsequent development involves a three-dimensional video reconstruction of a portion of the historic urban framework of the town, which was lost during a tragic aerial bombing at the end of the Second World War.This activity allows to virtually re-construct buildings and urban spaces that have disappeared for decades, reviving in those who have remained the memory of people and of a history only apparently forgotten.

The informative method proposed in the research is therefore increasingly proven to be an effective tool in preserving and transmitting the memory of a certain place, not only for the knowledge of the existing, but also for the virtual re-construction of lost spaces and social aspects that seem to no longer exist, but which can still play a leading role in the future choices of the design of the places.

Keywords

digital archive, virtual reconstruction, representation, accessibility, dissemination.

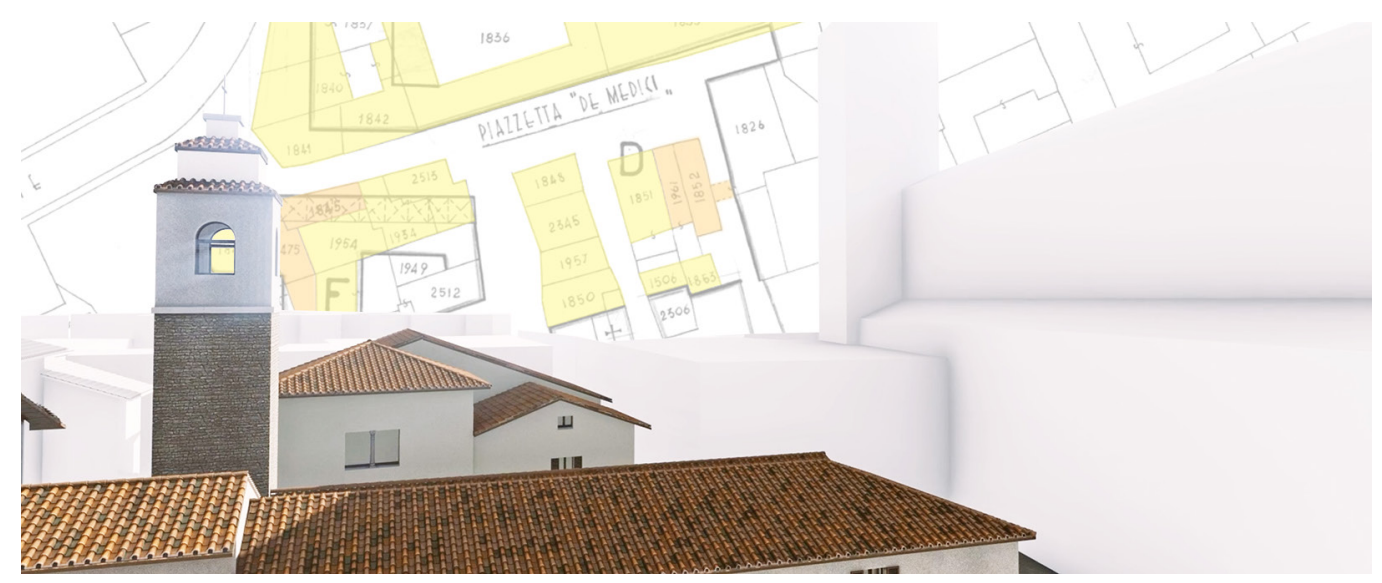




\section{The object of study}

When a local community is affected by a war event in the place where it lives, it does not only lose human lives and does not only lose buildings and objects. If the absence of a single piece represents an unbridgeable void for the individual, the value of the loss for the whole community is immeasurable and has repercussions that affect the generations to come over time $[I]$. They unknowingly live in urban spaces that have apparently stitched up the gashes and wounds, they go through voids where there were dense inhabited plots and pulsating sounds, smells and flavors.

Is it useful to deliver to the present a story that is not only told verbally or in writing, and to revive deleted places rather than show them in faded images of the time?

The research activity presented here takes as its starting point the tragic event of the bombing of Gavardo, which on January 29, 1945 affected the heart of the village by deleting some of its blocks: it was a watershed between a before and an after, a wound difficult to cure, as evidenced by the fact that the rubble remained for years in the urban space, next to a community that could not find a way to rethink the injured places.

It was therefore not easy to deal with this issue.

The goal was to return a piece of history to the current community. The operation relied on some inescapable concepts or keywords:

- understanding / simplification: the complexity of the local history must be simplified to reach all users (open content) and must be 'metabolizable'. The tools and languages must be simple, adaptable to different devices (user-friendly);

- implementation / participation: the user can contribute to enrich the database (open source);

- mending: a cultural bridge must be created to remedy a gap;

- accessibility / inclusiveness: the return of the memory is addressed to the whole community therefore the accessibility requirement must be declined in inclusivity. This involves the preparation of tactile panels or models, as well as videos with LIS language.

The project is therefore divided into several actions, the first of which had the objective of setting up an accessible 'memory box', an always implementable and open source digital archive that transforms the clues into pieces of a puzzle to be recomposed to return the urban history in an understandable way, to unravel the facts and the correspondences with the building fabric [2].

The second action is presented in the contribution: currently at an advanced state, it provides for the preparation of a virtual video-reconstruction of the historic center before the bombing, which allows the community to return that lost and never stitched up forma urbis. A preview of the research in progress and the video were proposed on the occasion of the

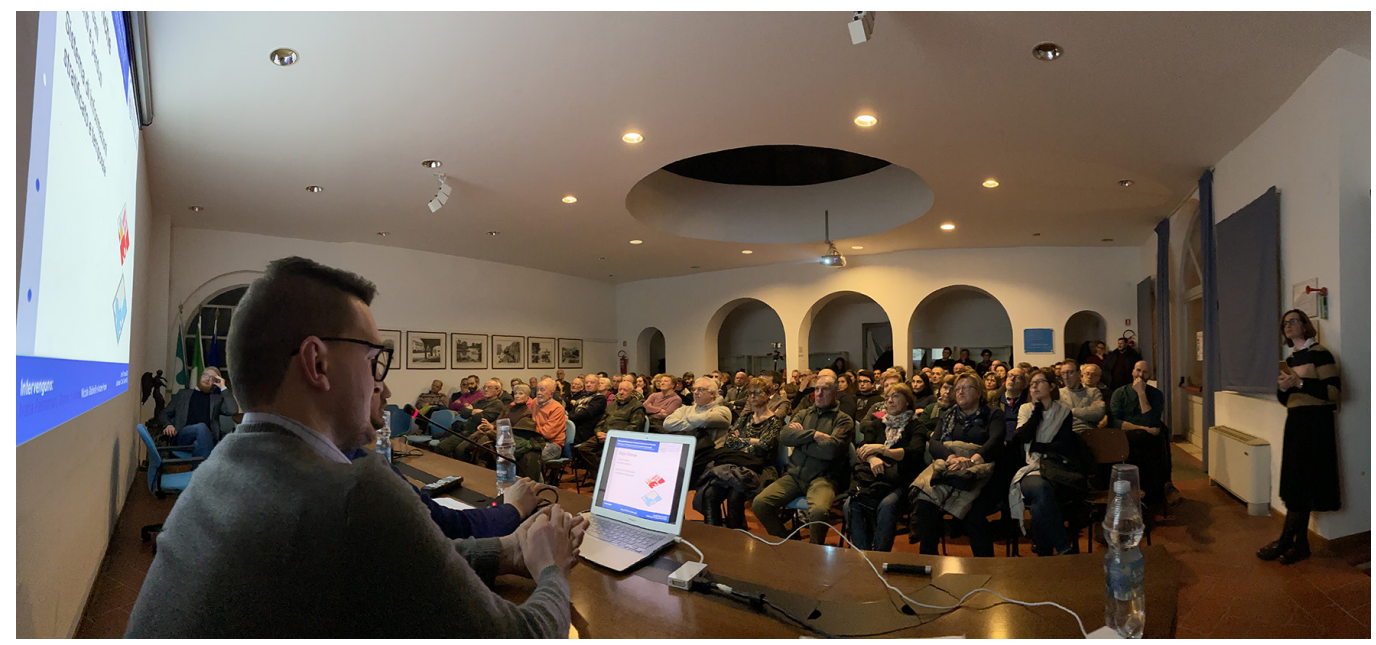


celebrations of the 75th anniversary of the bombing [3]: a packed room in which, alongside the few who had directly experienced the event, many citizens were able to descend into the streets of the village, view the shops and activities, have their history in their hand (fig. I). The reconstruction relies on photos and drawings of the time to dress the volumes. We also consider the bare version effective. It is like when you enter a closed environment for a long time, and you take off the white sheets that cover the furniture to find out what's underneath.

The 3D model, even in the bare version, can allow those who will remove that sheet to have their story at hand (fig. 2).

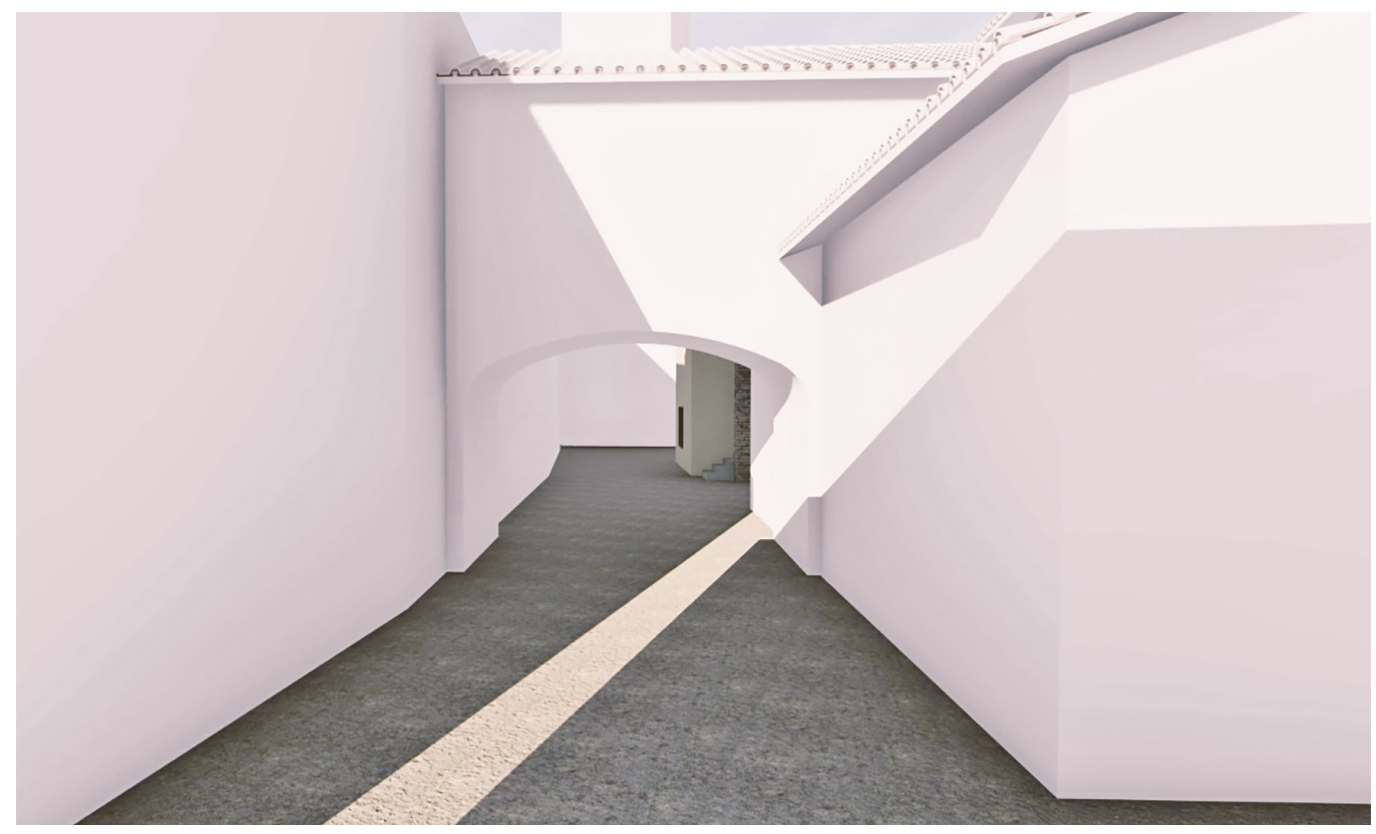

\section{A tool for the identity of a community}

It is reasonable to think that the identity of a community is also expressed as a function of the places it lives, of which the eye of the attentive researcher can read the signs and designs on the territory, including them of an anthropic or non-anthropic nature (fig. 3).

Recalling what Gianfranco Caniggia wrote about Saverio Muratori's lesson regarding the morphology of the inhabited center, it is "an organism in the making, therefore it can only show its becoming, therefore its current structural characteristics, through moments of formation-transformation in succession, which can be reconstructed through the logical and analogical reconstruction of the succession of phases, each time finished, graphically representable" [Caniggia 1988, p. I44]. The different phases can therefore be represented graphically, according to ways that can only be declined from time to time differently, according to the innovations that technology continuously offers us. The effectiveness of this research in the study of an inhabited center lies precisely in the possibility that it offers to provide an instrument in step with the times in which we live, authoritative for understanding the built, but at the same time easily exploitable by a vast audience of users, the same who will be able to implement the information in the database, guaranteeing the constant updating. An instrument of this type, in continuous development and evolution, can certainly be functional for greater awareness of technicians in the urban planning or architectural intervention, but it can guarantee a further step. The IT tool, the practical result of this research, allowing the virtual reconstruction of an area of Gavardo destroyed during the bombings of the Second World War, has in fact demonstrated not only the ability to function adequately to 
guarantee the architectural value of the urban fabric, but also to safeguard and enhance its social value, consisting of relationships and aggregations, rather than building, the attenuation of which causes irreparable damages over time, much more than physical damage.

Fig. 3. Wall texture in the historic center of Gavardo (photo by N Ghidinelli, A. Pasini).

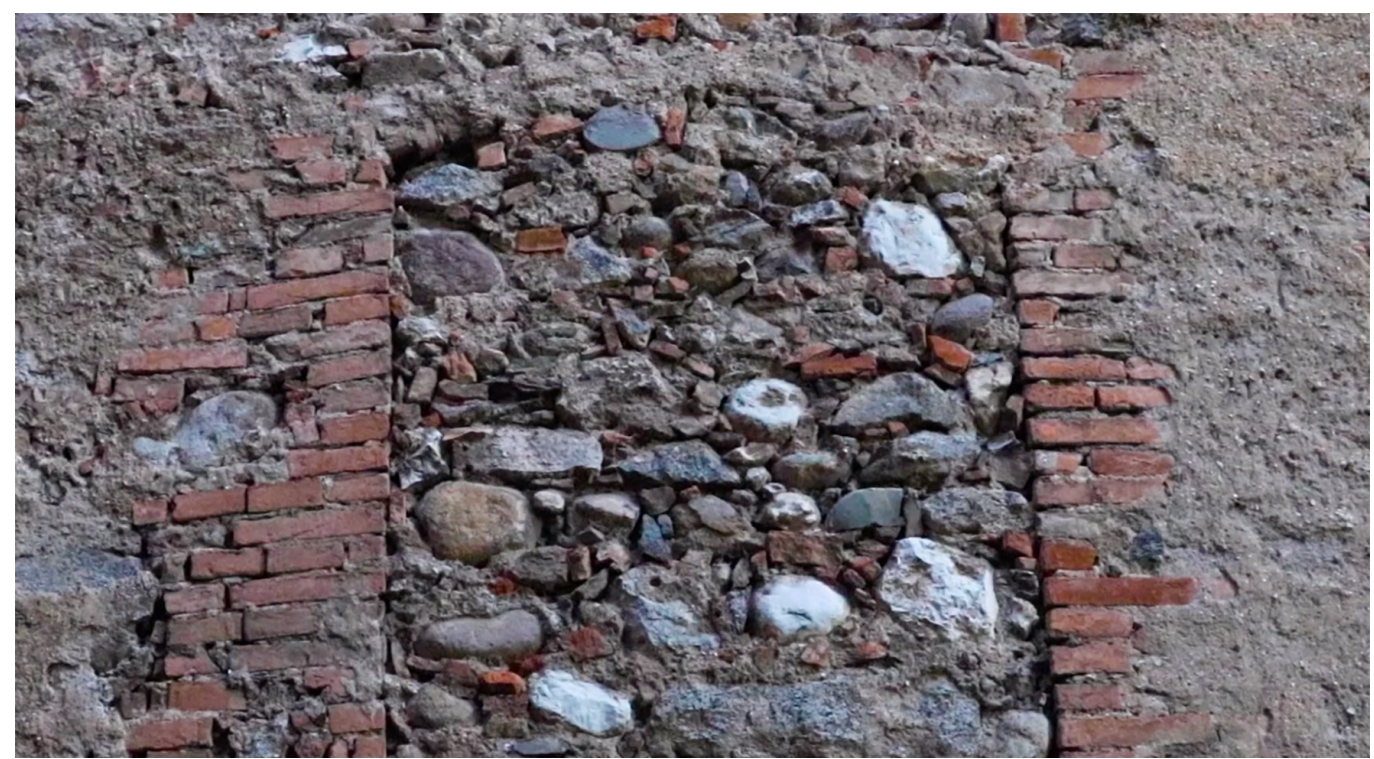

The informative method

The cultural heritage of a territory is an articulated system of images and stratified situations generated by the succession of natural and anthropic events. The method has the main objective of collecting the heterogeneous data deriving from research and detection and of systematizing them within a space that is easily accessible to different types of users and that allows their enhancement, so as to make cultural, historical, economic, naturalistic heritage

\title{
Ricerca archivistica e bibliografica
}

\author{
"Sapere" \\ Linee guida \\ Dati eterogenei
}
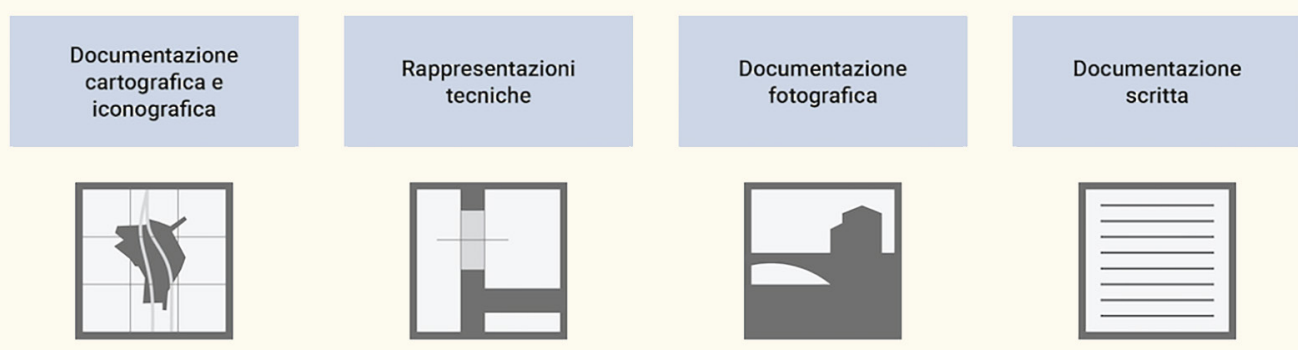
of a territory usable and to encourage the knowledge, empowerment and participation of the inhabitants (fig. 4). To encourage the highest involvement of users, it is important that the database is developed according to the dictates of responsive web design so as to facilitate its approach, that it is open source so that the user can offer, submitting his contributions to the curator, his supply of memory and knowledge of places, as well as open content, so that the contents of the virtual archive are shared.

The fundamental principle that allows us to pursue these objectives is the geolocation of information within a digital environment, thanks to which consultation and use of databases take on characteristics of efficiency, precision and reliability.

GavArch
Fig. 5. Scheme of the developed informative system (graphic elaboration by N.
Ghidinelli, A. Pasini).

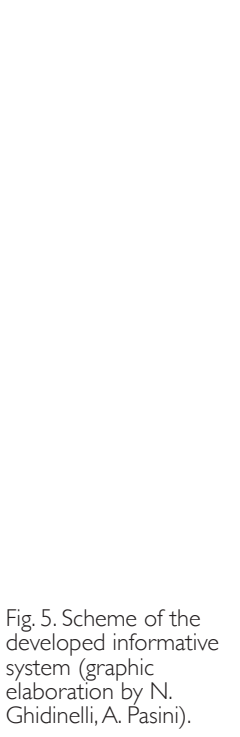

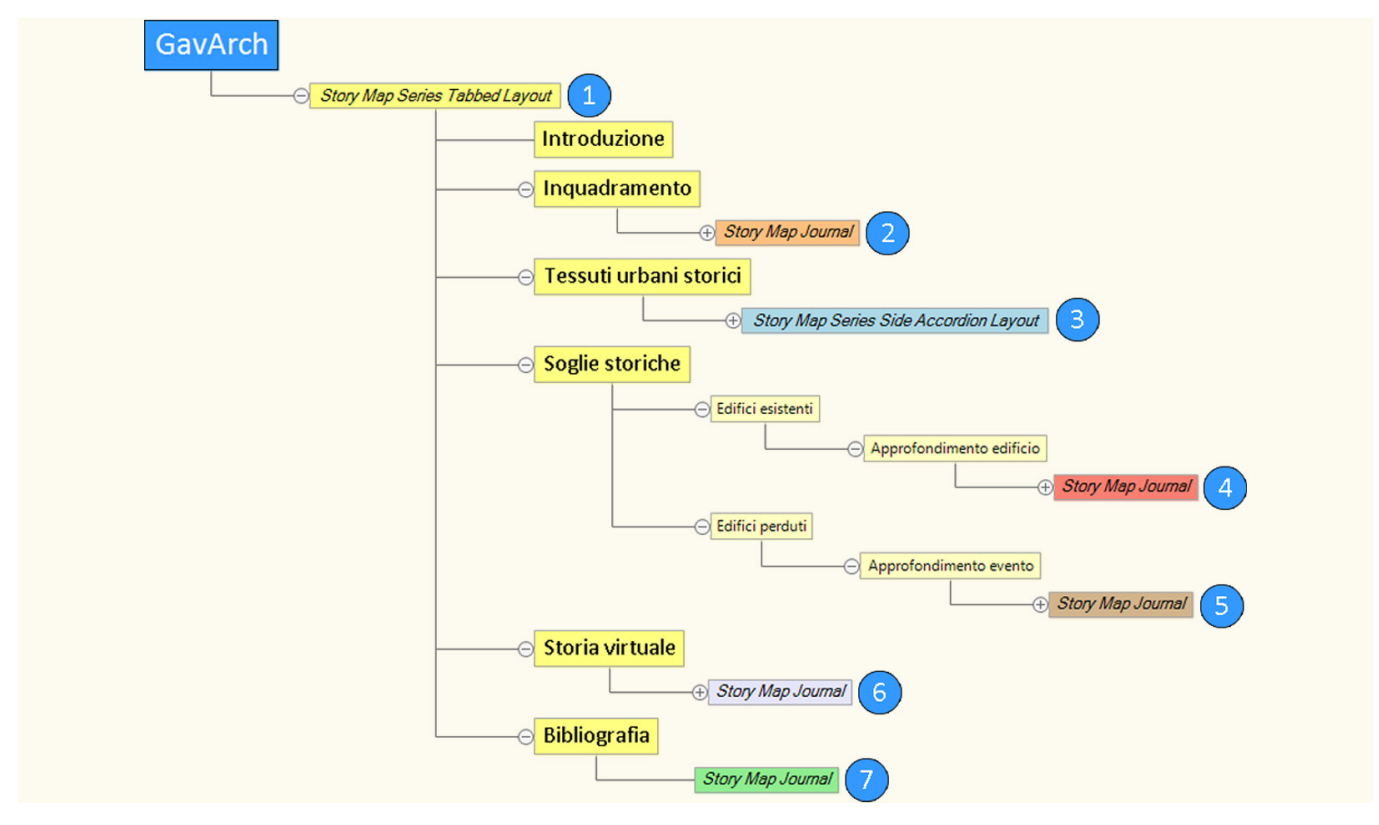

In order to summarize the urban morphological study of a territory, it was necessary to create a base on which connecting historical data, classifying urban fabrics according to their age, highlighting existing and those lost and thus forming a stratified information system with a temporal dimension.

Operationally, through the analysis and virtual re-elaboration of the various historical cartographies and their overlap through the key points of the existing, it was possible to reconstruct the urban fabrics related to the various historical thresholds.

Through the use of Territorial Information Systems, and through the use of a GIS (Geographic Information System) software, it was possible to process and organize the data and connect them to specific territorial entities, referring them spatially to the earth's surface thanks to their geographical coordinates (fig. 5).

Using a webGIS extension of the software, it was possible to share and manage the maps on the network, thus creating applications, called Story Maps, capable of combining maps with narrative texts and multimedia contents of various kinds using predefined models featuring a graphical interface intuitive, easy to understand and designed to automatically adapt to the various media used (smartphone, tablet, PC). Within the application, the map of the historical thresholds was superimposed on an orthophotographic base and it was possible to manage the graphic layout and assign alphanumeric data to the elements of the map by inserting for each building information relating to the name, the era of construction, the type of use and type of construction, to the address where it is located, thus allowing access to a further level of study. 


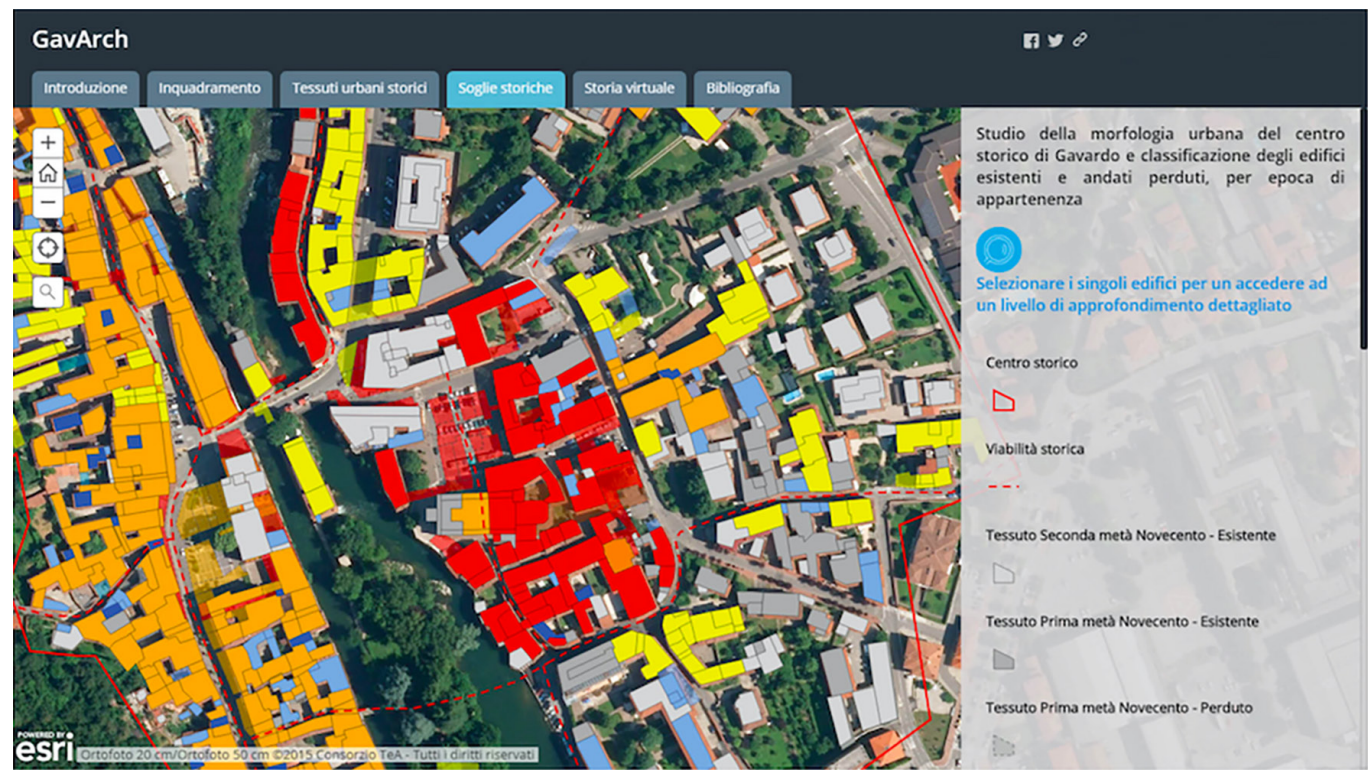

Seven Story Maps have been created, linked to each other through hypertext links with which a URL code is associated, thus constituting the basic general structure, configured through the graphical interface and the functionality of the Map Series Tabbed Layout template (fig. 6).

Through this approach it is possible to enhance the data and understand and know the history of a place both from a cultural and a technical point of view, going to create support for professionals and local administrations who can act through conscientious design choices. In future developments, considering a sensorial accessibility, it will be possible to process the information in tactile supports and decomposable plastic models in order to make the method usable even for weak users.
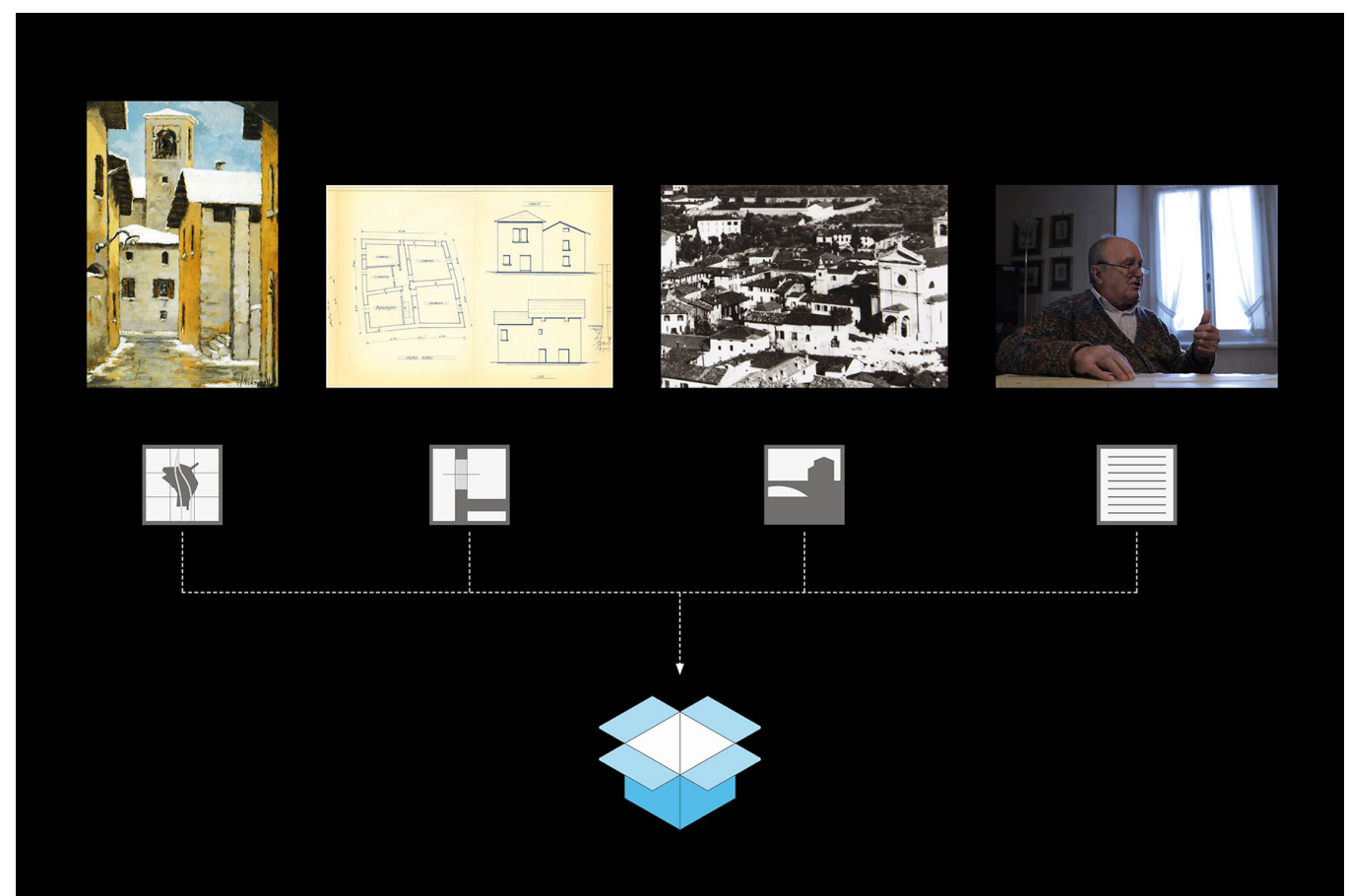

Fig. 7. The data collected for the digital re- 


\section{Digital reconstruction}

The developed method and the related data collected within the information system can be further developed in different independent research and study channels. The result of the overlapping of the information that is created within the temporal stratification of the historical thresholds, in fact shows a complex system of sediments of existing and lost buildings belonging to different eras which if interpreted and studied punctually allows you to develop an effective and communicative digital reconstruction, with a higher level of readability and greater detail.

The idea of developing a three-dimensional digital reconstruction of a lost place is the natural consequence of the possibility of using an information system that integrates different heterogeneous information deriving from historical archival research (cartographic and iconographic-illustrative data, geometric data, photographic data and narrative-descriptive data).

This process requires first of all the correct interpolation and interpretation of the information already available in the database and, more specifically, the finding of geometric data about the third dimension (height) of the lost buildings and of visual data that correctly describe the original envelope to obtain a result as realistic as possible. This operation takes place through a process of re-designing the drawing (transcription of all information,

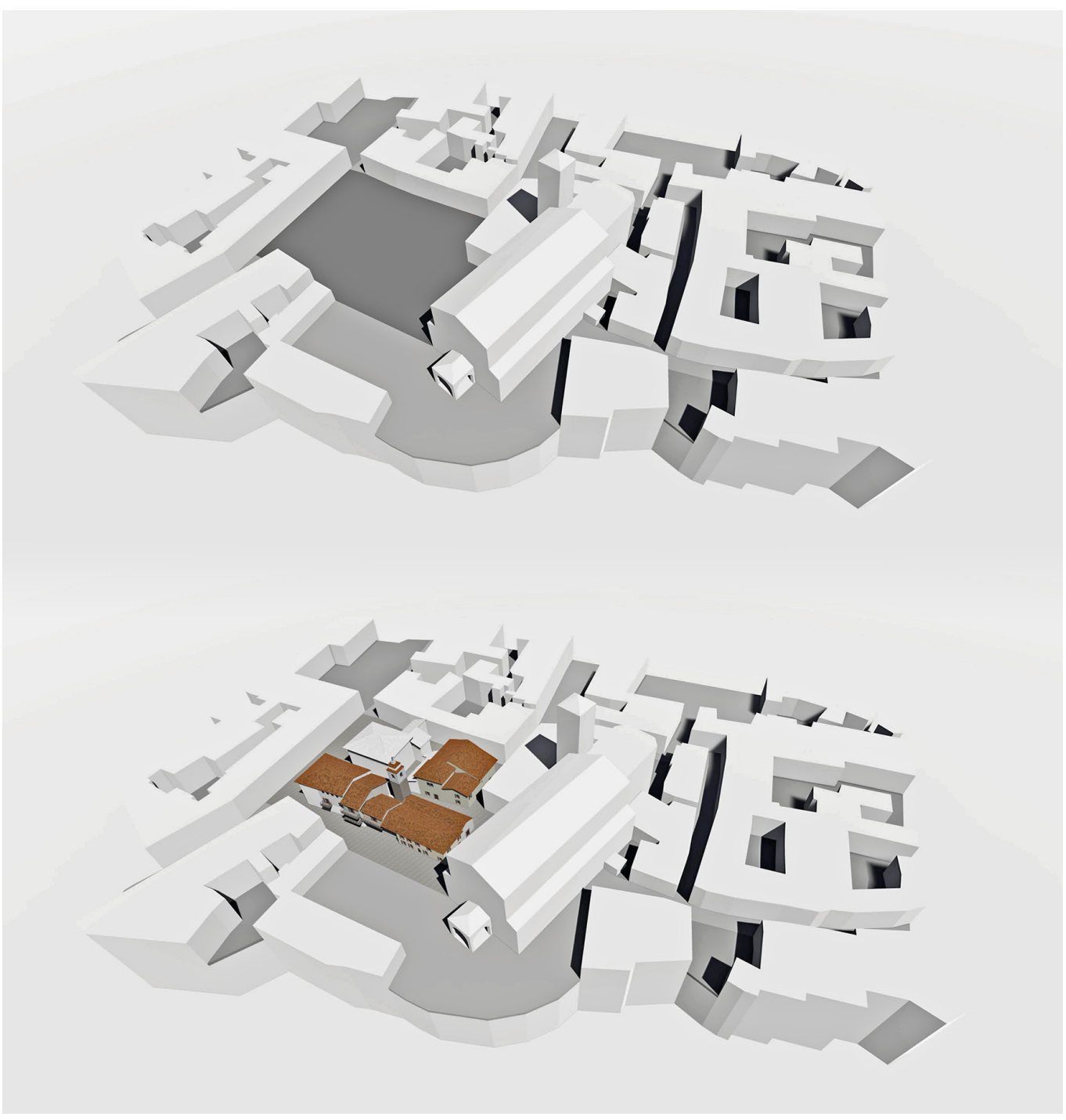


selection, verification and interpretation of the same) with consequent choices and interpretation of the data to be communicated. In this regard, to give a scientific feedback to the reconstruction, different levels of development of the details are identified so as to describe a qualitative volumetric reconstruction if there is less information and photographic-realistic if more information is available.

Within this process of punctual development of the method described above, it is important to find further narrative-descriptive information, through direct (through encounters and emotional dialogues) and indirect witnesses (through the reading of bibliographical sources about the topic) thanks to people who have lived, traveled and enjoyed these lost places to be rebuilt. It is important to underline this research, since it has an ambivalent value: on the one hand, finding and chasing lost data and in a reciprocal way preserving this data and information that immediately turns into heritage, memory and shared archival data in terms of enhancement, accessibility and knowledge (fig.7).

The collected data, once interpreted, were combined with each other through the scientific method of superimposing the information described above and implemented, redesigned, verified and analyzed within a three-dimensional modeling software to give the communication of this reconstruction to be kept in the archival heritage, legibility and a communication method that can be used by the widest possible number of users. A morphological redrawing was then carried out with the consequent study of shapes, elements and volumes. Subsequently, through the use of software that allows the translation of the model in 3D rendering, a redrawing was developed in terms of material surface treatment (texture, choice, evaluation and combination of materials) and simultaneously processing operations of image-atmosphere design and composition and scene assembly (choice and variation of different types of graphic rendering, light effects management, choice of communicative cut, presentation and personalization of the visual story) (fig. 8).

This kind of approach, together with the presentation of the three-dimensional reconstruction of the places lost to a heterogeneous group of people made up of recipient users who can recognize them as real memories and users who have a virtual memory, allows to consider some aspects for the future development.

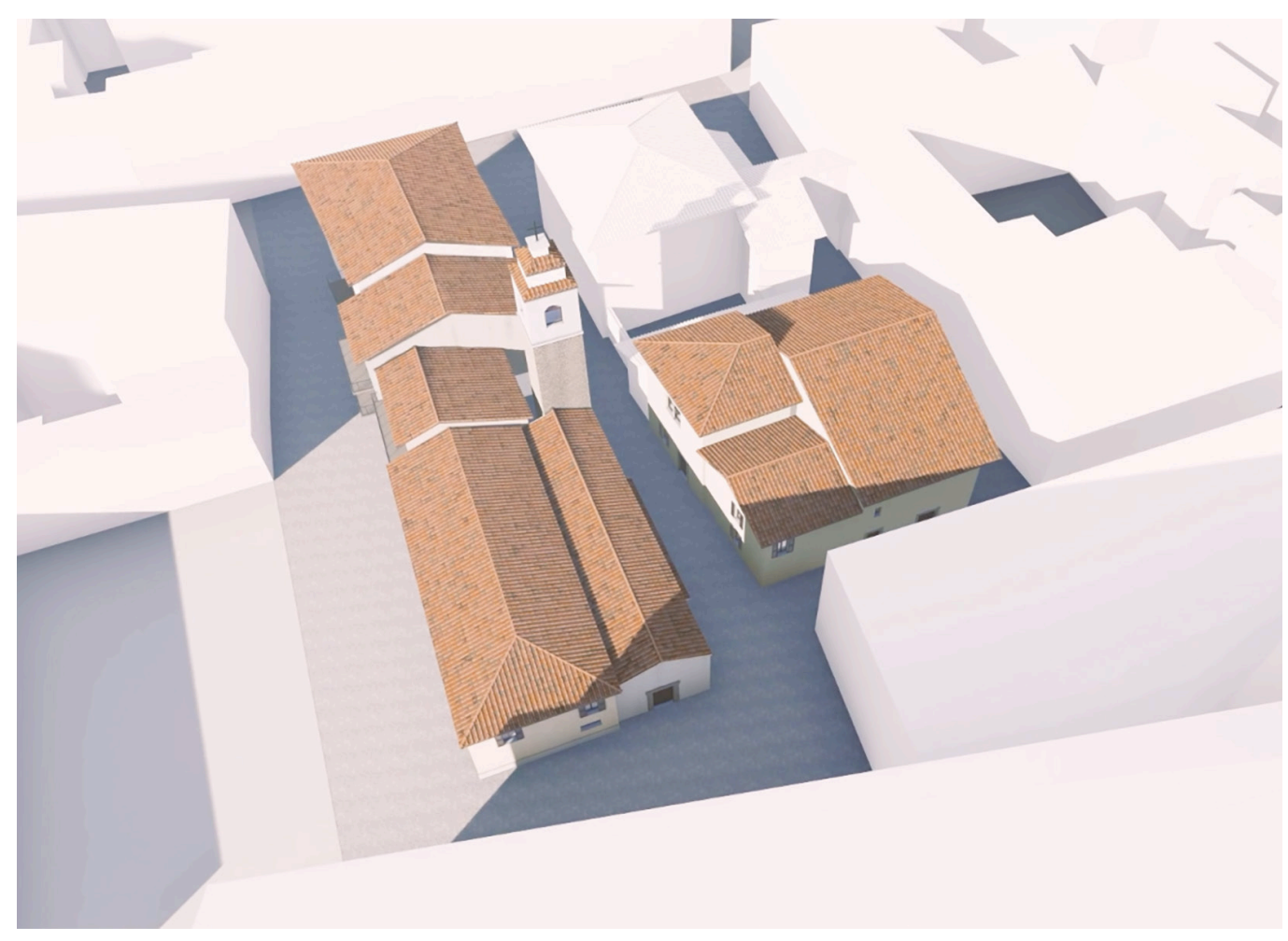


Pursued and achieved objectives

In front of a track, a sign of urban memory, we have all the tools to undertake a research on several levels, aimed at the acquisition of data that allow a reconstruction or re-stitching of the gap. This process, introduced into the urban reality, opens new scenarios of knowledge which, in addition to the merely architectural datum, add the human and social ones. In this way the most important value will be gained, that of the intimate correlation between buildings, urban spaces and the humanity that inhabited and lived them.

In the three-dimensional video reconstructions, then, we can ideally travel through those lost spaces by hearing the sounds of everyday life and the activities that were present there, and by placing in the right place destinations of use and people: that is, we can bring to light pieces of local history that were erased in seconds (fig. 9).

It is therefore really useful and important to put the memory box 'at hand', or to build an information system and method that preserve and make history and intangible heritage of a given place accessible.

Thanks to current technologies we can not only reconstruct destroyed places, but also re-propose the social and human aspects of a historical fragment. Today's community can draw lessons, sense of cohesion and solidarity from these, considering them as a driving force and engine of future choices and knowledge for a consistent handing down of the design of places (fig. 10).

\section{"La più grande perdita di questo tragico evento non possono essere solo gli edifici. Ricostruire la loro storia porta alla luce un'umanità andata perduta. Avere a portata di mano questa storia consente di mantenere viva la memoria di una comunità".}

Notes

[I] While sharing the objectives, methodologies and results of the research, it should be noted that Passamani is the author of paragraph The object of study and Pursued and achieved objectives; Fasolini is the author of paragraph A tool for the identity of a community; Ghidinelli is the author of paragraph The informative method; Pasini is the author of paragraph Digital reconstruction.

[2] This first step was presented in the paper A virtual archive to understand and communicate places' complexity and was presented in September 2019 at the STC 2019 conference in Salerno. The research team was composed of Passamani, Fasolini, Pasini and Ghidinelli.

3] The event was organized by the Municipal Administration as part of the demonstrations to commemorate the tragedy. The intervention "The history at hand to rebuild the historical core of Gavardo" was proposed on January 27, 2020 in Gavardo. The whole research group intervened. 


\section{References}

Bartolini Fabio (20I5). Dalla carta antica al sistema informativo territoriale: evoluzione storica dell'antico Canale dei Molini di Cesena. Cesena: Stilgraf.

Bruni Conter Gianbattista (2002). Quaderni della Quadra di Gavardo. Contributi alla conoscenza storica di un territorio. Numero 4. Brescia: Grafo2.

Caniggia Gianfranco (1988). Saverio Muratori. La didattica e il pensiero. In Montuori Marina (a cura di). Lezioni di progettazione. 10 maestri dell'architettura italiana. Milano: Electa.

Cetraro Faustino (201 I). Gis e WebGis a confronto. Cartografia applicata ai sistemi informativi territoriali. Roma: EPC Editore.

Chiavoni Emanuela, Docci Mario (2017). Saper leggere l'architettura. Bari: Editori Laterza.

Coppo Secondino (2002). Appunti di viaggio, un mazzo di fiori. In Mezzetti Carlo (a cura di) Gaspare de Fiore. Disegni, incisioni, progetti. Roma: Edizioni Kappa.

Fappani Antonio (a cura di) (1993). Enciclopedia Bresciana, Volume X. Brescia: Fondazione Opera Diocesana San Francesco di Sales

Fasolini Stefano (2007). I borghi del Bresciano. Proposta di rappresentazione simbolica per lo studio dei centri mercantili minori. Tesi di dottorato di ricerca in Beni Culturali. Politecnico di Torino. Tutor prof. Secondino Coppo.

Graci Giancarlo, Pileri Paolo, Sedazzari Marco (2008). GIS e ambiente. Guida all'uso di ArcGIS per l'analisi del territorio e la valutazione ambientale. Palermo: Dario Flaccovio Editore.

Munari Bruno (1992). Semplificare è più difficile. In Munari Bruno. Verbale scritto. Mantova: Corraini Edizioni.

Munari Bruno (2016). I laboratori tattili. Mantova: Corraini Edizioni. (I ed. 1985).

Passamani Bonomi Ivana (2009). Le acque di Gavardo. In Salvatore Nocivelli Laura (a cura di). Brescia nel solco del fiume Chiese. Roccafranca: Compagnia della Stampa.

Passamani Ivana, Fasolini Stefano, Ghidinelli Nicola, Pasini Andrea (2019). Un archivio virtuale per comprendere e comunicare la complessità dei luoghi. In Fiore Pierfrancesco, D'Andria Emanuela (a cura di). Small towns... from problem to resource. Sustainable strategies for the valorization of building, landscape and cultural heritage in inland areas. Milano: Franco Angeli

Associazione Museo "Gruppo Grotte", Biblioteca Civica "E. Bertuetti" (1984). Gavardo da salvare: il patrimonio abitativo di Gavardo, Sopraponte e Soprazocco. Gavardo.

Associazione Museo "Gruppo Grotte”, Biblioteca Civica "E. Bertuetti” ( 1988). II volto storico di Gavardo, Gavardo: Industrie grafiche.

\section{Authors}

Stefano Fasolini, Università degli Studi di Brescia, stefano.fasolini@unibs.it

Ivana Passamani, Università degli Studi di Brescia, ivana.passamani@unibs.it

Nicola Ghidinelli, Università degli Studi di Brescia, ghidinelli.nicola@gmail.com

Andrea Pasini, Università degli Studi di Brescia, andreapasini2290@gmail.com

To cite this chapter. Fasolini Stefano,Passamani Ivana, Ghidinelli Nicola, Pasini andrea (2020). La storia a portata di mano per ri-costruire la memoria di una comunità/History at your doorstep acknowledging the legacy of a community. In Arena A., Arena M., Brandolino R.G., Colistra D., Ginex G., Mediati D., Nucifora S., Raffa P. (a cura di). Connettere. Un disegno per annodare e tessere. Atti del $42^{\circ}$ Convegno Internazionale dei Docenti delle Discipline della Rappresentazione/Connecting. Drawing for weaving relationships. Proceedings of the 42 th International Conference of Representation Disciplines Teachers. Milano: FrancoAngeli, pp. 2|42-2|6|. 